\title{
Contents, Vol. 44, 1982
}

\section{No. 1 Original Paper}

Occlusion of Stenon's Duct by Prolamine: a Possible Treatment of Chronic Parotitis? Pre liminary Experience from Animal Experiments

Schroder, M.; Chilla, R.; Arglebe, C; Droese, M 1

The Correlation between the Vestibulo-Ocular System and the Vestibulo-Spinal System in Ménière's Disease Based on Categorical Principal Component Analysis

Imoto, T.; Nakai, Y 6

Oculomotor Abnormalities after Labyrinthine and Cerebellar Lesion. A Case Report

Cherubino, M.; Mira, E.; Mevio, E 24

On-Efl $7 / 8$ ct in Brainstem Electric Response Audiometry. Consequences for the Use of Tone-

Bursts

Debruyne, F.; Forrez, G 36

Haemangioma of the Maxillary Sinus. Some Comments on Pre-Operative Diagnosis

Tsutsumiuchi, K.; Hasegawa, M.; Okuno, H.; Watanabe, I.; Okayasu, I.; Suzuki, S. . 43

Enzyme Histochemical and Histographic Data on Normal Human Facial Muscles

Schwarting, S.; Schroder, M.; Stennert, E.; Goebel, H.H 51

Book Review 60

Announcements 60

No. 2 Original Paper

Quantitated Determination of Proteins in Perilymph in Patients with Acoustic Neuromas

Thomsen, J.; Saxtrup, O.; Tos, M 61

Spinal Proteins in Patients with Acoustic Neuromas

Thomsen, J.; Saxtrup, O.; Tos, M 66

Flunarizine in Vertigo. A Double-Blind Placebo-Controlled Cross-Over Evaluation of a

Constant-Dose Schedule

Oosterveld, W.J 72

Tympanic Membrane Homografts. Histological Findings in a Human Case

Zambonin Zallone, A.; Teti, A.; Iurato, S 81

Long-Term Prognostic Significance of Serial Tympanometry. A Cohort Study of Preschool

Children

Fiellau-Nikolajsen, M.; Lous, J 90

The Effect of Glycerol on Cochlear Blood Flow

Larsen, H.C.; Angelborg, C; Hultcrantz, E 101

Aural Polypi: a Histopathological and Histochemical Study

Gaafar, H; Maher, A.; Al-Ghazzawi, E 108

Amylase in the Tonsil

Chen, H.-S 116

Book Reviews $\quad 119$

Announcements $\quad 120$ 
Contents

III

No. 3 Original Paper

Otitis Externa - Bacteriological Survey

Feinmesser, R.; Wiesel, Y.M.; Argaman, M.; Gay, 1121

Possibilities of High Resolution CT Scanning in Ear and Sinus Pathology

Clement, P.A.R.; De Smedt, E 126

Pituitary Tumor Producing Only Thyrotropin. A Case Report

Anniko, M.; Backlund, E.-O.; Lundquist, P.-G.; Samuelsson, K..; Ritzén, M.; Tribukait, B.; Wersäll, J 134

Sleep Apnea Syndrome Caused by Acromegalia and the Treatment with a Reduction Plasty of the Tongue. Case Report

Afzelius, L.-E.; Elmqvist, D.; Laurin, S.; Risberg, A.M.; Åberg, M 142

Temporal Bone Findings in Friedreich's Ataxia

Igarashi, M.; Miller, R.H.; O-Uchi, T.; King, A.I 146

Ototoxicity of Aminoglycoside Antibiotics by Rapid Intravenous Injection

Ohtani, I.; Ohtsuki, K.; Aikawa, T.; Omata, T.; Ouchi, J.; Saito, T 156

The Cricoid Cartilage: Observations on Some Roentgen Variants

Nidecker, A.; Hochstetter, A. von; Hug, J 170

Book Reviews $\quad 178$

No. 4 Original Paper

A Critical Review of Experimental Observations on Ear-Drum Structure and Function

Funnell, W.R.J.; Laszlo, C.A 181

Posttraumatic Sensorineural Hearing Loss. A Prospective Long-Term Study

Koefoed-Nielsen, B.; Tos, M 206

Spike Artefact Associated with Fast Eye Movements in Electronystagmography and Its Importance in the Automatic Analysis of Saccades

Jäntti, V 216

Monoaminergic Mechanisms Mediating Asymmetry after Unilateral Labyrinthectomy in the Frog

Barth, R.D 226

Treatment of Ménière's Disease with Isosorbide

Kitahara, M.; Takeda, T.; Yazawa, Y.; Matsubara, H.; Kitano, H 232

Book Reviews 239

Announcement 240

No. 5 Original Paper

Cervical Mycobacteriosis. Relation to BCG Vaccination, Treatment and Results of Treat ment

Afzelius, L.-E.; Békassy, A.; Garwicz, S 241

Non-Lethal Midline Granuloma of the Nose

Talaat, A.M.; Bassiouny, A.M.; Kutty, M.K 244

Surgical Treatment of Atrophic Rhinitis by Closure of the Nostril

Moustafa, H.; Abdel-Latif, S.; El-Fiky, S.; Hagras, M 257

The Effect of an Oral Combined Preparation (Antihistamine and Decongestant) on Eustachian Tube Function in the Common Cold

Virtanen, $\mathrm{H} \quad 268$ 
IV

Contents

Computer Analysis of Fixation-Suppression of Caloric Nystagmus

Kato, I.; Nakamura, T.; Koike, Y.; Watanabe, Y 277

Eye Movements Induced by Electrical Stimulation in the Rabbit's Mesodiencephalon

Ishikawa, K.; Satoh, K.; Togawa, K 288

Book Review $\quad 300$

Announcement $\quad 300$

No. 6 Original Paper

Complications of Otitis Media

Pfaltz, C.R 301

Regenerated Middle Ear Mucosa after Tympanoplasty

Gamoletti, R.; Zini, C; Sanna, M.; Bellomi, A 310

Giant Cell Tumor of the Temporal Bone. A Case Report

Zelig, S.; Eilon, A.; Deutsch, E.; Ariel, 1318

Human Papilloma Virus (HPV) Antigens in Lesions of Laryngeal Squamous Cell Carcinomas

Syrjänen, K.; Syrjänen, S.; Pyrhönen, S 323

Malignant Fibrous Histiocytoma of the Nasal Septum. A Report of an Unusual Lesion

Nishizawa, S.; Matsumoto, K.; Funasaka, S.; Imamura, T.; Mohri, N 335

The Value of X-Ray Examination in the Diagnosis of Tracheobronchial Foreign Bodies in Infants and Children

Gaafar, H.; Abdel-Dayem, M.; Talaat, M.; Mandour, M 340

Response of Upper Airway Resistance to Rebreathing in the Rabbit. The Interrupting Effect

of $\alpha$-Adrenergic Blockers

Hasegawa, M.; Ikeda, M.; Watanabe, 1349

Book Reviews 356

Preliminary Announcement $\quad 357$

Author Index $\quad 358$

Subject Index $\quad 359$

S. Karger Medical and Scientific Publishers $\cdot$ Basel $\square$ Miinchen $\cdot$ Paris $\square$ London $\cdot$ New York

- Tokyo - Sydney

Drug Dosage

The authors and the publisher have exerted every effort to ensure that drug selection and dosage set forth in this text are in accord with current recommendations and practice at the time of publication. However, in view of ongoing research, changes in government regulations, and the constant flow of information relating to drug therapy and drug reactions, the reader is urged to check the package insert for each drug for any change in indications and dosage and for added warnings and precautions. This is particularly important when the recommended agent is a new and/or infrequently employed drug.

All rights reserved.

No part of this publication may be translated into other languages, reproduced or utilized in any form or by any means, electronic or mechanical, including photocopying, recording, microcopying, or by any information storage and retrieval system, without permission in writing from the publisher.

S. Karger AG, P.O. Box, CH-4009 Basel (Switzerland) Printed in Switzerland by Thür AG Offsetdruck, Pratteln 